\title{
Association of nutritional status with socio-economic and demographic variables of under five year old Nepalese children
}

\author{
Nushin Karkuki Osguei ${ }^{1}$, CG Nicholas Mascie-Taylor*1
}

Received: 29 June 2018

Published: 8 Apr 2019

Abstract

Background: To see which socioeconomic and demographic variables associate with the nutritional status of under five-year old Nepalese children. This nationwide study provides a comprehensive analysis on of risk factors for childhood acute and chronic undernutrion.

Methods: The Nepal Demographic and Health Survey 2006 was used as a cross sectional data source. A total of 3630 children were analysed. Standard Z-score were used for children. Anaemia was also defined using international norms. The statistical analysis used was binary logistic regression, which was performed using SPSS software package for Windows. The cut-off for a significant result was $<0.05$.

Results: The results showed that $1680(46.3 \%)$ of children were stunted, $1384(38.1 \%)$ were underweight, $513(14.1 \%)$ were wasted and 1631 (44.9\%) were anaemic. Underweight and stunting showed significant association with mother's education and ethnicity. All nutritional factors were associated with ecological zone and standard of living. Also, underweight and wasting showed a significant relationship with religion.

Conclusion: Maternal education, ecological zone, ethnicity and standard of living were the main predictors of child nutritional status.

Keywords: Children undernutrition, Standard of living, Stunting

Conflicts of Interest: None declared

Funding: Yousef Jameel Scholarship

\section{*This work has been published under CC BY-NC-SA 1.0 license.}

Copyright $@$ Iran University of Medical Sciences

Cite this article as: Karkuki Osguei N, Mascie-Taylor CGN. Association of nutritional status with socio-economic and demographic variables of under five year old Nepalese children. Med J Islam Repub Iran. 2019 (8 Apr);33:28. https://doi.org/10.47176/mjiri.33.28

\section{Introduction}

In developing countries, the primary causes of undernutrition are infectious diseases and dietary inadequacy, both in terms of quality and quantity (1). Secondary causes include household food insecurity, unhealthy household environment, inadequate care, lack of health services and income poverty. The latter is acknowledged as the main

Corresponding author: Dr CG Nicholas Mascie-Taylor,nmt1@cam.ac.uk

\footnotetext{
1. Department of Public Health and Primary Care, University of Cambridge, Worts
} Causeway, Cambridge, CB1 8RN, UK driver of undernutrition.

The global burden of stunting is greater than underweight and wasting (2). According to the Global database of the World Health Organization on child growth and malnutrition, which is derived from the analysis of 388 national surveys from 139 countries (3), it was estimated

$\uparrow$ What is "already known" in this topic:

In Nepalese population, several studies have been performed to address the association between nutritional status and demographic and socioeconomic factors of children. However, a comprehensive study that adjusts this relationship for a large number of possible risk factors has not been performed yet.

\section{$\rightarrow$ What this article adds:}

The current study addresses this issue and provides a full and detailed snapshot of socioeconomic variables that affect child nutrition in Nepal. The main message of this manuscript is that the overall priority for nutritional health policy in Nepal should be reduction of undernutrition especially in the mountain zones. 
that among children under five years old, 16.0\% (104 million) were underweight, 26.7\% (171 million, 167 million in developing country) were stunted (4) and 9.0\% were wasted. The overall prevalence of underweight was higher in Africa and Asia (19.3\% and 19.5\%, respectively). Also, the highest prevalence of stunting was observed in Africa and Asia (38.2\% and 27.5\%, respectively), while the percentage of wasting was quite similar in Africa and Asia (10.0\% and $10.8 \%$, respectively) (5).

Anaemia is also a public health problem in many developing countries. Using the 1993-2005 WHO database on anaemia, it has been estimated that anaemia affects a quarter (1.62 billion) of people in the World (6). The prevalence of anaemia is $9 \%$ in developed counties and $43.0 \%$ in developing counties. Globally, it is estimated that $47.4 \%$ of children under five years old, are anaemic. The estimates show that Asia is affected by anaemia more than other continents, followed by Africa (6).

Nepal is one of the developing countries in which undernutrition is a serious public health problem in children less than five years old. Undernutrition is recognised as a leading factor that leads to increased morbidity and mortality in children. Anaemia is also a major health problem among young children in this country.

So far, there have been several comprehensive health studies and reports in Nepal, which emphasize the problems of undernutrition in Nepal. For example, the report in 1984, which focused on the key determinants of nutrition, showed a high prevalence of stunting $(65 \%)$ in children living in the districts of Bara and Rautahat of the Terai zone (7). The results of another study, which followed up the growth of 5-12 months children in the Bhaktapur district, showed that the growth curves of a significant number of these children fell below the $3^{\text {rd }}$ percentile after one year of age (8). A high prevalence of undernutrition has also been reported in other age groups including $45 \%$ stunting and $52 \%$ underweight in 6-10 years old children (9), and $40 \%$ in the general population (2).

Anaemia is another public health problem with high prevalence $(10,11)$. According to the Nepal's Ministry of Health (12), 78\% of children aged 6-59 months are anaemic. The most common causes of anaemia in Nepal are considered to be inadequate intake of iron from food and parasitic infections including malaria, which is endemic in some parts of the country (12).

The present study, attempted to determine the main socio-economic, demographic and geographic factors which were associated with undernutrition and anaemia in under five years old Nepalese children. Anaemia and undernutrition, especially in younger children, are important public health issues.

\section{Methods}

Nepal is located in South-East Asia in the lap of the Himalayas. Nepal is made up of Mountain, Hills and the Terai (plains) ecological zones and is divided into the five developmental regions of Far-western, Mid-western, Western, Central and Eastern. Total population of Nepal is 28 million (13) and is ethnically diverse with over 100 castes.
As reported in the 2011 census, 123 mother tongues are spoken in Nepal. Most people, 44.6\% $(11,826,953)$, speak Nepali as their mother tongue and $11.7 \%(3,092,530)$ speak Maithili (14). Nepal is socially stratified in a caste system. There is no clear distinction between caste and ethnicity in colloquial Nepali (15). Recently, caste and ethnicity have taken a crucial role in Nepalese society following the governmental changes that led to establishment of a federal republic.

The 2006 Nepal Demographic and Health Survey (12) obtained a cross sectional information from a random sample of households in which there were young children. The sampling frame for this DHS survey was based on enumeration areas used in the 2001 Nepal population census. The country is made up of 14 zones which are subdivided into a total of 75 districts. The districts are then subdivided into Village Development Committees (VDCs) and VDCs were subdivided into the wards. Ward and subward were used as the primary sampling unit (PSU) in rural areas. A two-stage stratified, probability proportional to size (PPS) sampling resulted in the final sample size of 9,036 households. Using the PPS technique, a total of 260 PSU (178 in rural and 82 in urban areas) were selected in the first stage by systematic sampling. The households in the selected wards were enumerated in the second stage. Using systematic sampling, 36 households in rural areas and 30 households in urban areas were selected. Based on this sampling method, the design effect was considered in all analyses.

In total 3630 children were studied from across the country. The criteria for inclusion of the children in this study consisted of having a Nepalese-speaking mother and having an age younger than five years old. All the children for whom a complete profile of age, height, weight and socio-economic and demographic factors (parental education, parental occupation, households' demographic characteristics and households' standard of living) could not be obtained were excluded from this study. Height and weight were measured and in children the z-scores of height-for-age (HAZ), weight-for-age (WAZ) and weightfor-height (WHZ) were calculated using the WHO 2006 reference values. Children with WAZ, HAZ or WHZ values of $<-2$ were classified as underweight, stunted or wasted, respectively. The analyses controlled the impact of children's age and sex on z-scores. Haemoglobin concentration was determined from a finger prick of blood and use of a portable hemocue. At the population level, haemoglobin concentration is the most reliable indicator for definition of anaemia (16). An altitude adjusted haemoglobin concentration was calculated using the following CDC formula (17-20):

$$
{ }_{\mathrm{ad}} \mathrm{Hb}=-0.32 \times(\text { Alt } \times 0.0033)+0.22 \times(\text { Alt } \times 0.0033)
$$

Where ${ }_{\mathrm{ad}} \mathrm{Hb}$ is adjustment haemoglobin value in $\mathrm{g} / \mathrm{l}$ and Alt is altitude in metres. The calculated ${ }_{\mathrm{ad}} \mathrm{Hb}$ was rounded up or down to the nearest $1 \mathrm{~g} / \mathrm{L}$ value and it was subtracted from each individual's actual haemoglobin reading. The adjusted haemoglobin concentrations were used in all analyses.

The cut-off for anaemia is $<110 \mathrm{~g} / 1$ for children.

The demographic and socio-economic indicators used in 
this study were (1) parental education with four categories of (i) no education, (ii) primary, (iii) secondary or (iv) higher education, (2) parental occupation with five categories of (i) professional, technician, managerial and clerical (PTMC), (ii) sales and services (S \& S), (iii) agricultural, (iv) skilled and unskilled manual (S \& U Manual), and (v) unemployed, and finally, (3) household's geographic characteristics with three categories of (i) place of residence (urban/rural), (ii) ecological zone (Terai, Hill and Mountain) and (iii) geographical region (Far-western, Mid-western, Western, Central and Eastern). Households were also compared by their size into two groups of 1-4 and 5 and more family members. Households were categorised into four religious groups of Hindu, Buddhist, Muslim and other religions (Christian and Kirat).

Ethnicity was categorised into seven groups (disadvantaged non-Dalit, Dalit, disadvantage Janajatis, upper caste, advantaged Janajatis, religious minority and other) according to the methodologies detailed in a MEASURE DHS program report (21), a World Bank report (22) and a UK Department for International Development report (23). The households' standard of living were categorized into having (1) safe drinking water, which is defined as the water with physical, chemical and microbial characteristics that meet national standards or WHO guidelines, and access to drinking water means that the source is less than 1 kilometre (30 minutes by foot) away from its place of use (2) toilet meeting MDG, (3) electricity with binary categories of 'yes' or 'no', (4) type of cooking fuel, and (5) main material used in floor, wall and roof construction with two categories of poor and not poor. Also, the households were classified according to ownership of assets based on having more than one asset (television, radio, telephone, bicycle and motorbike) or having no asset. Ownership of assets is a factor that is related to household's wealth and hence children's nutritional status.
Ownership of radio and television were included as they provided capacity of receiving health messages. Possession of vehicle and its type is related to the possibilities of transportation in emergency medical conditions.

Binary logistic regression analyses with "Enter" variable selection method were used to examine the relationship between child nutritional indictors and the socioeconomic and demographic variables. Multicollinearity between independent variables has been checked. In regression models, using VIF (variance inflation factor), tolerance $(1 / \mathrm{VIF})$, eigenvalues and condition index, the independent variables including all socio-economic and demographic variables, were tested for the presence of multicollinearity. The Hosmer-Lemeshow test was used to assess the goodness of fit.

In order to explore the interaction effects, the second order interactions between independent variables used in this report were analysed using binary logistic regressions. The statistical analysis was performed with the SPSS software package for Windows, version 17 released in 2008 (Chicago: SPSS Inc). The cut-off for a significant result was $<0.05$.

\section{Results}

Children

The demographic characteristics of 3630 children entered into this study are presented in Table 1. Socioeconomic variables were used in this study including: parental education, parental occupation, place of residence, ecological zones, region, number of household members, religion, drinking water meeting $\mathrm{MDG}$, toilet meeting MDG, electricity, cooking fuel, assets, main floor materials, main walls materials and main roof materials. The variables, which showed significant association with nutritional status, are presented in the tables.

There was clear evidence of undernutrition with 1680

Table 1. Demographic characteristics of children (children aged $<5$ years, Nepal Demographic and Health Survey 2006)

\begin{tabular}{|c|c|c|c|}
\hline Variables & & Number & Percent $(\%)$ \\
\hline \multirow[t]{2}{*}{ Sex } & Male & 1913 & 52.7 \\
\hline & Female & 1717 & 47.3 \\
\hline \multirow[t]{4}{*}{ Education status of mother } & Higher & 98 & 2.7 \\
\hline & Secondary & 719 & 19.8 \\
\hline & Primary & 655 & 18.0 \\
\hline & No education & 2158 & 59.4 \\
\hline \multirow[t]{4}{*}{ Education status of father } & Higher & 294 & 8.1 \\
\hline & Secondary & 1454 & 40.1 \\
\hline & Primary & 1046 & 28.8 \\
\hline & No education & 836 & 23.0 \\
\hline \multirow[t]{2}{*}{ Number of household members } & $1-4$ & 988 & 27.2 \\
\hline & $\geq 5$ & 2642 & 72.8 \\
\hline \multirow[t]{5}{*}{ Mother's occupation } & PTMC* & 56 & 1.5 \\
\hline & $\mathrm{S} \& \mathrm{~S} \dagger$ & 166 & 4.6 \\
\hline & Agricultural & 2712 & 74.7 \\
\hline & S \& U Manual $\ddagger$ & 91 & 2.5 \\
\hline & Unemployed & 605 & 16.7 \\
\hline \multirow[t]{5}{*}{ Father's occupation } & PTMC* & 584 & 16.1 \\
\hline & $\mathrm{S} \& \mathrm{~S} \uparrow$ & 614 & 16.9 \\
\hline & Agricultural & 1411 & 38.9 \\
\hline & S \& U Manual & 900 & 24.8 \\
\hline & Unemployed & 121 & 3.3 \\
\hline \multirow[t]{4}{*}{ Religion } & Hindu & 3156 & 86.9 \\
\hline & Buddhist & 242 & 6.7 \\
\hline & Muslim & 138 & 3.8 \\
\hline & Other & 94 & 2.6 \\
\hline
\end{tabular}




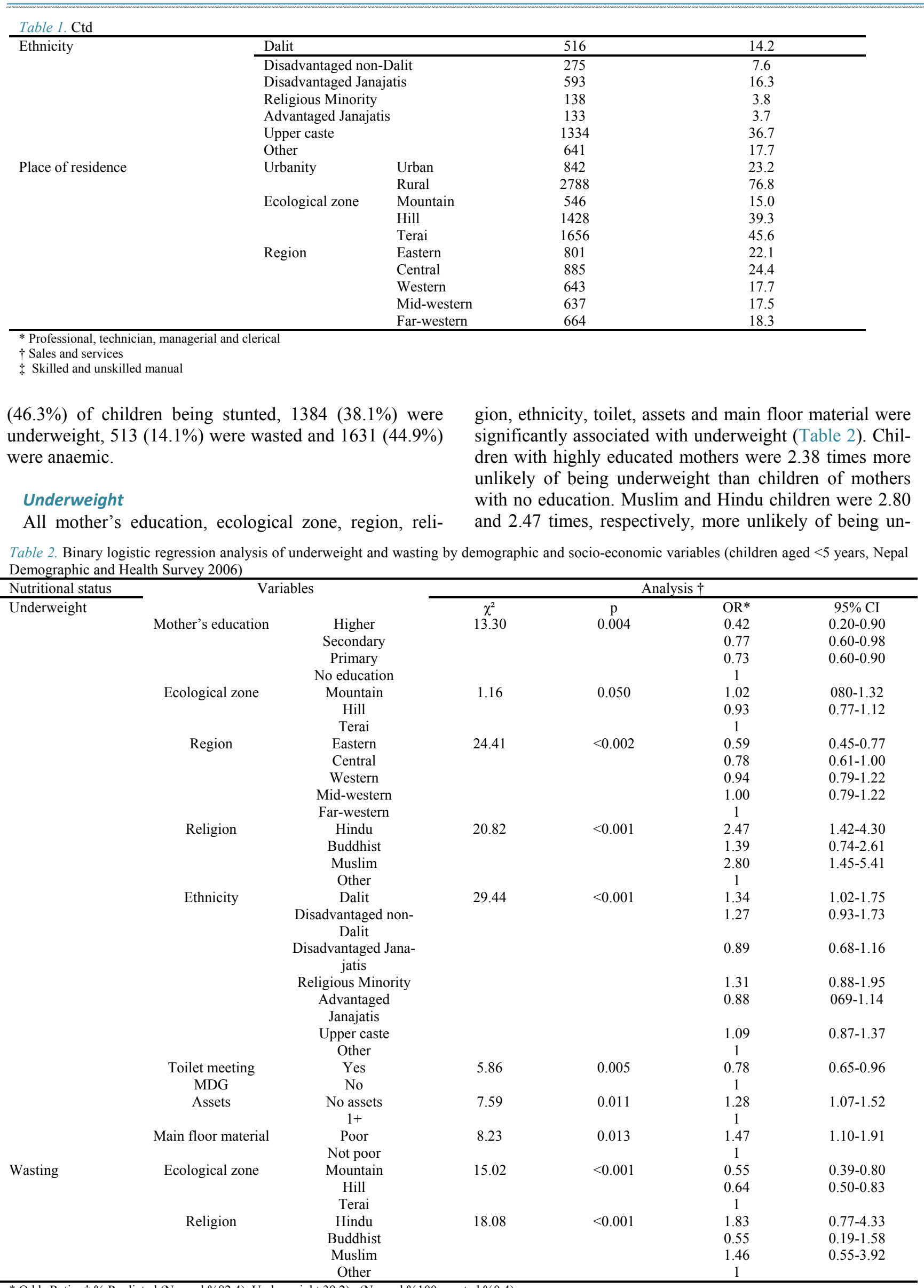

\footnotetext{
* Odds Ratio, $\uparrow \%$ Predicted (Normal \%82.4), Underweight 39.2 ) , (Normal \%100, wasted \%0.4)
} 
derweight as compared with other religions including Buddhist and other minority religion groups. Children from the Dalit ethnic group were 1.34 times more unlikely of being underweight than the six ethnicities listed in Table 2, and children living in households with no assets were 1.28 more likely to be underweight as compared with others. When all the variables were entered into the model, $82.4 \%$ of normal children were correctly predicted as were $39.2 \%$ of underweight children. The overall $p$ value was $<0.001$. When the interaction effects between independent variables were examined, the overall effect was not significant. Table 3 presents the results of analysis of the independent variables, which did not show significant association with underweight.

\section{Wasting}

Binary logistic regression analysis for wasting (Table 2) indicated that only ecological zone and religion showed a significant association with wasting. The model with all the variables predicted only $0.4 \%$ of wasted children but $100 \%$ of normal children. The overall $p$ value was $<0.001$. When the interaction effects between independent variables were examined, the overall effect was not significant. Table 4 presents the results of analysis of the independent variables, which did not show significant association with wasting.

\section{Stunting}

The results of the binary logistic regression analysis for stunting and normal children are presented in Table 5. Six variables were significantly associated with stunting, namely: mother's education, ecological zone, region, ethnicity, toilet and assets. Children whose mothers had higher education were 3.57 times more unlikely of being

Table 3. Binary logistic regression analysis of underweight by demographic and socio-economic variables (children aged $<5$ years, Nepal Demographic and Health Survey 2006)

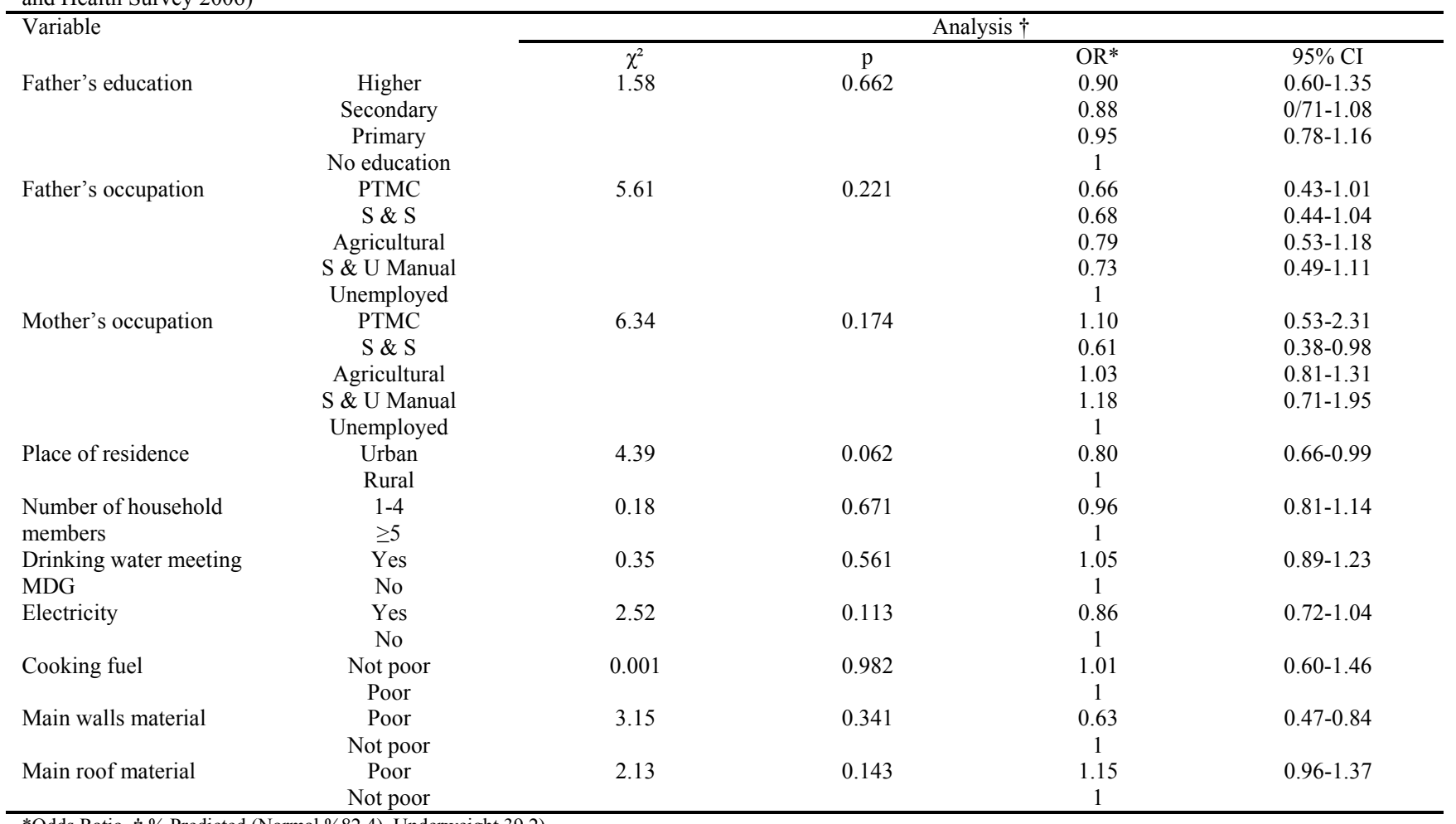

*Odds Ratio, $\uparrow \%$ Predicted (Normal \%82.4), Underweight 39.2 )

Table 4. Binary logistic regression analysis of wasting by socio-economic and demographic variables (children aged $<5$ years, Nepal Demographic and Health Survey 2006)

\begin{tabular}{|c|c|c|c|c|c|}
\hline \multirow[t]{2}{*}{ Variable } & & \multicolumn{4}{|c|}{ Analysis $\dagger$} \\
\hline & & $\chi^{2}$ & $\bar{p}$ & $\mathrm{OR}^{*}$ & $95 \% \mathrm{CI}$ \\
\hline \multirow{2}{*}{ Place of residence } & Urban & 2.70 & 0.104 & 0.79 & $0.59-1.05$ \\
\hline & Rural & & & 1 & \\
\hline \multirow[t]{5}{*}{ Region } & Eastern & 2.73 & 0.952 & 0.61 & $0.43-0.86$ \\
\hline & Central & & & 0.69 & $0.50-0.95$ \\
\hline & Western & & & 0.66 & $0.47-0.94$ \\
\hline & Mid-western & & & 0.75 & $0.55-1.02$ \\
\hline & Far-western & & & 1 & \\
\hline \multirow[t]{7}{*}{ Ethnicity } & Dalit & 7.35 & 0.253 & 1.05 & $0.75-1.48$ \\
\hline & Disadvantaged non-Dalit & & & 1.02 & $0.69-1.51$ \\
\hline & Disadvantaged Janajatis & & & 0.54 & $0.36-0.81$ \\
\hline & Religious Minority & & & 0.45 & $0.24-0.76$ \\
\hline & Advantaged Janajatis & & & 0.29 & $0.11-0.75$ \\
\hline & Upper caste & & & 0.69 & $0.50-0.97$ \\
\hline & Other & & & 1 & \\
\hline
\end{tabular}




\begin{tabular}{|c|c|c|c|c|c|}
\hline \multicolumn{6}{|l|}{ Table 4. Ctd } \\
\hline \multirow[t]{2}{*}{ Number of household members } & $1-4$ & 0.38 & 0.531 & 0.93 & $0.73-1.18$ \\
\hline & $\geq 5$ & & & 1 & \\
\hline \multirow{2}{*}{ Drinking water meeting MDG } & Yes & 0.64 & 0.424 & 1.09 & $0.88-1.36$ \\
\hline & No & & & 1 & \\
\hline \multirow[t]{2}{*}{ Toilet meeting MDG } & Yes & 3.22 & 0.073 & 0.77 & $0.58-1.03$ \\
\hline & No & & & 1 & \\
\hline \multirow{2}{*}{ Electricity } & Yes & 0.19 & 0.661 & 1.10 & $0.83-1.35$ \\
\hline & No & & & 1 & \\
\hline \multirow[t]{2}{*}{ Cooking fuel } & Not poor & 2.77 & 0.104 & 1.52 & $0.94-2.48$ \\
\hline & Poor & & & 1 & \\
\hline \multirow[t]{2}{*}{ Assets } & No assets & 0.01 & 0.943 & 0.99 & $0.77-1.27$ \\
\hline & $1+$ & & & 1 & \\
\hline \multirow[t]{2}{*}{ Main floor material } & Poor & 5.77 & 0.061 & 1.59 & $1.10-2.33$ \\
\hline & Not poor & & & 1 & \\
\hline \multirow[t]{2}{*}{ Main walls material } & Poor & 4.95 & 0.074 & 0.51 & $0.33-0.78$ \\
\hline & Not poor & & & 1 & \\
\hline \multirow[t]{2}{*}{ Main roof material } & Poor & 0.72 & 0.401 & 0.90 & $0.70-1.15$ \\
\hline & Not poor & & & 1 & \\
\hline \multirow[t]{4}{*}{ Father's education } & Higher & 3.27 & 0.353 & 0.85 & $0.50-1.45$ \\
\hline & Secondary & & & 0.79 & $0.59-1.06$ \\
\hline & Primary & & & 0.97 & $0.75-1.27$ \\
\hline & No education & & & 1 & \\
\hline \multirow{4}{*}{ Mother's education } & Higher & 6.34 & 0.151 & 0.85 & $0.50-1.45$ \\
\hline & Secondary & & & 0.79 & $0.59-1.07$ \\
\hline & Primary & & & 0.94 & $0.75-1.27$ \\
\hline & No education & & & 1 & \\
\hline \multirow[t]{5}{*}{ Father's occupation } & PTMC & 7.76 & 0.104 & 0.53 & $0.29-0.96$ \\
\hline & $S \& S$ & & & 0.69 & $0.38-1.24$ \\
\hline & Agricultural & & & 0.81 & $0.47-1.26$ \\
\hline & S \& U Manual & & & 0.72 & $0.41-1.26$ \\
\hline & Unemployed & & & 1 & \\
\hline \multirow[t]{5}{*}{ Mother's occupation } & PTMC & 4.57 & 0.332 & 2.55 & $1.11-5.89$ \\
\hline & $S \& S$ & & & 0.10 & $0.54-1.84$ \\
\hline & Agricultural & & & 1.01 & $0.74-1.38$ \\
\hline & S \& U Manual & & & 1.10 & $0.52-2.25$ \\
\hline & Unemployed & & & 1 & \\
\hline
\end{tabular}

Table 5. Binary logistic regression analysis of stunting and anaemia by demographic and socio-economic variables (children aged $<5$ years, Nepal Demographic and Health Survey 2006)

\begin{tabular}{|c|c|c|c|c|c|c|}
\hline \multirow{2}{*}{$\begin{array}{l}\text { Nutritional status } \\
\text { Stunting }\end{array}$} & \multicolumn{2}{|r|}{ Variables } & \multicolumn{4}{|c|}{ Analysis $\dagger$} \\
\hline & & & $\chi^{2}$ & $\mathrm{p}$ & $\mathrm{OR}^{*}$ & $95 \% \mathrm{CI}$ \\
\hline & Mother's & Higher & 25.88 & $<0.001$ & 0.28 & $0.14-0.57$ \\
\hline & education & Secondary & & & 0.58 & $0.46-0.74$ \\
\hline & & Primary & & & 0.84 & $0.69-1.03$ \\
\hline & & No education & & & 1 & \\
\hline & Ecological & Mountain & 10.14 & 0.001 & 1.42 & $1.11-1.82$ \\
\hline & zone & Hill & & & 1.30 & $1.08-1.57$ \\
\hline & & Terai & & & 1 & \\
\hline & Region & Eastern & 42.11 & $<0.001$ & 0.49 & $0.38-0.64$ \\
\hline & & Central & & & 0.89 & $0.69-1.15$ \\
\hline & & Western & & & 0.93 & $0.71-1.22$ \\
\hline & & Mid-western & & & 0.95 & $0.74-1.21$ \\
\hline & & Far-western & & & 1 & \\
\hline & Ethnicity & Dalit & 27.62 & $<0.001$ & 1.76 & $1.33-2.33$ \\
\hline & & Disadvantaged non-Dalit & & & 1.92 & $1.39-2.68$ \\
\hline & & Disadvantaged Janajatis & & & 1.65 & $1.25-2.18$ \\
\hline & & Religious Minority & & & 1.08 & $0.68-1.74$ \\
\hline & & Advantaged Janajatis & & & 2.19 & $1.45-3.30$ \\
\hline & & Upper caste & & & 1.11 & $0.75-1.66$ \\
\hline & & Other & & & 1 & \\
\hline & Toilet meeting & Yes & 7.84 & 0.005 & 0.76 & $0.62-092$ \\
\hline & MDG & No & & & 1 & \\
\hline & Assets & No assets & 9.42 & 0.002 & 1.33 & $1.11-1.59$ \\
\hline & & $1+$ & & & 1 & \\
\hline
\end{tabular}

stunted than children of mothers with no education. Children living in the hills and mountains were 1.30 and 1.42 times, respectively, more probable of being stunted than children living in the Terai. On the other hand, the main regional differences were that children from the Eastern region were about 2.04 times more unlikely of being stunted than children from other regions. Children from the Advantaged Janajatis ethnic group were 2.19 times more probable of being stunted than the other ethnicities. Children of households without assets were 1.33 times more probable of being stunted than others. With all the variables in the model, $72.5 \%$ of normal children were 


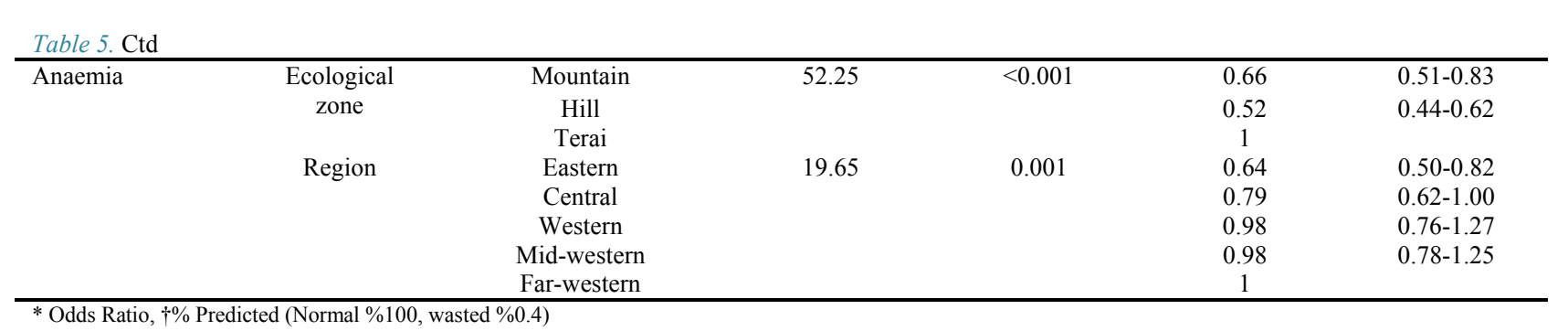

correctly predicted and so were $61.5 \%$ of stunted children. The overall $\mathrm{p}$ value was $<0.001$. When the interaction effects between independent variables were examined, the overall effect was not significant. Table 6 presents the results of analysis of the independent variables, which did not show significant association with stunting.

\section{Anaemia}

Ecological zone and region were significantly associated with anaemia. Living in the Terai, and Far-western regions were all associated with greater risk of being anaemic (Table 5). Also, 72.3\% of normal children and $45.9 \%$ of anaemic children were correctly predicted. The overall $\mathrm{p}$ value was $<0.001$. When the interaction effects between independent variables were examined, the overall effect was not significant. Table 7 presents the results of analysis of the independent variables, which did not show significant association with anaemia.

\section{Discussion}

Undernutrition and anaemia are still public health problems in Nepalese children age $<5$ years old. Results from this study imply a long term burden of poor socioeconomic and demographic status.

Maternal education was significantly associated with underweight and stunting and children with educated mothers were less likely to be undernourished. Other Nepalese studies have found a strong association between maternal education and children's nutritional status. For example, it has been found that children of mothers with no education were 3.7 times more probable of being stunted than children of mothers who had passed the School Leaving Certificate (24). Many studies have highlighted the importance of maternal education as a key determinant of children's growth and nutritional status (25).

The influence of mother's education on child's nutritional status might be due to the fact that educated moth-

Table 6. Binary logistic regression analysis of stunting by demographic and socio-economic variables (children aged $<5$ years, Nepal Demographic and Health Survey 2006)

\begin{tabular}{|c|c|c|c|c|c|}
\hline \multirow[t]{2}{*}{ Variable } & & \multicolumn{4}{|c|}{ Analysis $\dagger$} \\
\hline & & $\chi^{2}$ & $\mathrm{p}$ & $\mathrm{OR}^{*}$ & $95 \% \mathrm{CI}$ \\
\hline \multirow[t]{4}{*}{ Father's education } & Higher & 2.47 & 0.483 & 0.78 & $0.52-1.16$ \\
\hline & Secondary & & & 0.91 & $0.74-1.13$ \\
\hline & Primary & & & 1.02 & $0.83-1.25$ \\
\hline & No education & & & 1 & \\
\hline \multirow[t]{5}{*}{ Father's occupation } & PTMC & 5.76 & 0.322 & 0.59 & $0.38-0.92$ \\
\hline & $\mathrm{S} \& \mathrm{~S}$ & & & 0.47 & $0.30-0.73$ \\
\hline & Agricultural & & & 0.62 & $0.40-0.94$ \\
\hline & S \& U Manual & & & 0.68 & $0.44-1.05$ \\
\hline & Unemployed & & & 1 & \\
\hline \multirow[t]{5}{*}{ Mother's occupation } & PTMC & 6.53 & 0.161 & 1.13 & $0.56-2.28$ \\
\hline & $\mathrm{S} \& \mathrm{~S}$ & & & 0.70 & $0.46-1.10$ \\
\hline & Agricultural & & & 0.77 & $0.60-0.98$ \\
\hline & S \& U Manual & & & 0.95 & $0.58-1.57$ \\
\hline & Unemployed & & & 1 & \\
\hline \multirow[t]{2}{*}{ Place of residence } & Urban & 4.58 & 0.242 & 0.73 & $0.59-0.89$ \\
\hline & Rural & & & 1 & \\
\hline \multirow{2}{*}{$\begin{array}{l}\text { Number of household } \\
\text { members }\end{array}$} & $1-4$ & 0.63 & 0.431 & 0.93 & $0.79-1.11$ \\
\hline & $\geq 5$ & & & 1 & \\
\hline \multirow[t]{4}{*}{ Religion } & Hindu & 1.03 & 0.604 & 1.23 & $0.76-1.99$ \\
\hline & Buddhist & & & 1.33 & $0.76-2.32$ \\
\hline & Muslim & & & 1.45 & $0.86-2.75$ \\
\hline & Other & & & 1 & \\
\hline \multirow{4}{*}{$\begin{array}{l}\text { Drinking water meet- } \\
\text { ing MDG } \\
\text { Electricity }\end{array}$} & Yes & 0.20 & 0.651 & 1.04 & $0.88-1.22$ \\
\hline & No & & & 1 & \\
\hline & Yes & 0.30 & 0.583 & 0.95 & $0.79-1.14$ \\
\hline & No & & & 1 & \\
\hline \multirow[t]{2}{*}{ Cooking fuel } & Not poor & 6.52 & 0.071 & 0.63 & $0.44-0.90$ \\
\hline & Poor & & & 1 & \\
\hline \multirow[t]{2}{*}{ Main floor material } & No assets & 2.52 & 0.114 & 1.23 & $0.95-1.59$ \\
\hline & $1+$ & & & 1 & \\
\hline \multirow[t]{2}{*}{ Main walls material } & Poor & 1.59 & 0.212 & 0.84 & $0.63-1.11$ \\
\hline & Not poor & & & 1 & \\
\hline \multirow[t]{2}{*}{ Main roof material } & Poor & 2.76 & 0.091 & 1.17 & $0.97-1.41$ \\
\hline & Not poor & & & 1 & \\
\hline
\end{tabular}


Table 7. Binary logistic regression analysis of anaemia by demographic and socio-economic variables (children aged $<5$ years, Nepal Demographic and Health Survey 2006)

\begin{tabular}{|c|c|c|c|c|c|}
\hline \multirow[t]{2}{*}{ Variable } & & \multicolumn{4}{|c|}{ Analysis $\dagger$} \\
\hline & & $\chi^{2}$ & $\mathrm{p}$ & $\mathrm{OR}^{*}$ & $95 \% \mathrm{CI}$ \\
\hline \multirow[t]{2}{*}{ Place of residence } & Urban & 5.47 & 0.08 & 1.37 & $1.13-1.65$ \\
\hline & Rural & & & 1 & \\
\hline \multirow[t]{7}{*}{ Ethnicity } & Dalit & 8.26 & 0.06 & 1.36 & $1.05-1.78$ \\
\hline & Disadvantaged non-Dalit & & & 1.07 & $0.78-1.46$ \\
\hline & Disadvantaged Janajatis & & & 1.40 & $1.08-1.83$ \\
\hline & Religious Minority & & & 1.35 & $0.98-1.56$ \\
\hline & Advantaged Janajatis & & & 1.29 & $0.83-1.98$ \\
\hline & Upper caste & & & 1.47 & $1.15-1.87$ \\
\hline & Other & & & 1 & \\
\hline \multirow[t]{4}{*}{ Religion } & Hindu & 1.26 & 0.53 & 1.01 & $0.64-1.59$ \\
\hline & Buddhist & & & 1.20 & $0.71-2.04$ \\
\hline & Muslim & & & 1.32 & $0.86-2.28$ \\
\hline & Other & & & 1 & \\
\hline \multirow{2}{*}{$\begin{array}{l}\text { Number of household } \\
\text { members }\end{array}$} & $1-4$ & 0.61 & 0.44 & 0.94 & $0.80-1.10$ \\
\hline & $\geq 5$ & & & 1 & \\
\hline \multirow{2}{*}{$\begin{array}{l}\text { Drinking water meet- } \\
\text { ing MDG }\end{array}$} & Yes & 1.61 & 0.21 & 0.91 & $0.78-1.10$ \\
\hline & No & & & 1 & \\
\hline \multirow[t]{2}{*}{ Toilet meeting MDG } & Yes & 3.55 & 0.06 & 1.20 & $0.10-1.44$ \\
\hline & No & & & 1 & \\
\hline \multirow[t]{2}{*}{ Electricity } & Yes & 0.05 & 0.82 & 0.98 & $0.82-1.17$ \\
\hline & No & & & 1 & \\
\hline Cooking fuel & $\begin{array}{l}\text { Not poor } \\
\text { Poor }\end{array}$ & 1.76 & 0.19 & $\begin{array}{c}1.24 \\
1\end{array}$ & $0.90-1.70$ \\
\hline Assets & $\begin{array}{c}\text { No assets } \\
1+\end{array}$ & 0.67 & 0.41 & $\begin{array}{c}0.93 \\
1\end{array}$ & $0.78-1.11$ \\
\hline \multirow[t]{2}{*}{ Main floor material } & Poor & 2.26 & 0.13 & 1.20 & $0.95-1.52$ \\
\hline & Not poor & & & 1 & \\
\hline \multirow[t]{2}{*}{ Main walls material } & Poor & 1.82 & 0.17 & 1.20 & $0.92-1.57$ \\
\hline & Not poor & & & 1 & \\
\hline \multirow[t]{2}{*}{ Main roof material } & Poor & 0.03 & 0.87 & 1.02 & $0.85-1.21$ \\
\hline & Not poor & & & 1 & \\
\hline \multirow[t]{4}{*}{ Father's education } & Higher & 0.39 & 0.943 & 1.06 & $0.73-1.52$ \\
\hline & Secondary & & & 1.05 & $0.86-1.30$ \\
\hline & Primary & & & 1.01 & $0.83-1.22$ \\
\hline & No education & & & 1 & \\
\hline \multirow[t]{4}{*}{ Mother's education } & Higher & 3.03 & 0.391 & 1.11 & $0.64-1.93$ \\
\hline & Secondary & & & 1.18 & $0.94-1.49$ \\
\hline & Primary & & & 1.15 & $0.95-1.40$ \\
\hline & No education & & & 1 & \\
\hline \multirow[t]{5}{*}{ Father's occupation } & PTMC & 2.75 & 0.602 & 1.03 & $0.66-1.52$ \\
\hline & $S \& S$ & & & 1.15 & $0.76-1.75$ \\
\hline & Agricultural & & & 1.10 & $0.74-1.62$ \\
\hline & S \& U Manual & & & 0.98 & $0.66-1.47$ \\
\hline & Unemployed & & & 1 & \\
\hline \multirow[t]{5}{*}{ Mother's occupation } & PTMC & 6.93 & 0.071 & 1.14 & $0.60-2.17$ \\
\hline & $S \& S$ & & & 1.23 & $0.83-1.81$ \\
\hline & Agricultural & & & 0.84 & $0.67-1.10$ \\
\hline & S \& U Manual & & & 1.52 & $0.92-2.51$ \\
\hline & Unemployed & & & 1 & \\
\hline
\end{tabular}

$*$ Odds Ratio, $\uparrow \%$ Predicted (Normal \%72.3, anaemic \%45.9)

ers not only invest in their children's food ingredients, but also in their health and education. Additionally, they may be more likely to realise when their children are ill and seek health care earlier (26).

Children living in the Terai were more likely to be underweight and wasted while children from the mountain zones were more probable of being stunted. These findings are in agreement with WHO reports which show a higher prevalence of childhood chronic undernutrition in those living in the mountains (27). The high prevalence of undernutrition in the mountains might be explained by the harsh terrain, difficult transportation, remoteness and lack of communication and health facilities in this zone. Also, mountains are economically less developed in comparison with hills and Terai. For example, the per capita income and share in national income are lowest in the mountains and highest in the Terai (28).

Western districts are less developed than Eastern regions with regards to their economic infrastructure, job market and transportation. Also, they have less favourable natural factors needed for productive farming such as the quality of farming soil, the amount of rainfall and duration of crop growing season (29). This pattern has been seen in other reports including the 2009 UN World Food Program report from Nepal (28).

Children from the Terai and western region were more anaemic as compared with children living in the hills and mountains. Also, lower consumption of iron-rich foods has been reported in the Western region (12). It should be noted that in the current report the haemoglobin concen- 
tration has been adjusted with altitude.

Muslim children were significantly more underweight and wasted than children from other religions. These findings are in agreement with other studies, e.g. a report from India showing that the rate of undernutrition in Christian children is less than Muslim and Hindu children (30).

This study showed that stunting and underweight had significant association with ethnicity of children, and especially, compared with other ethnicities, children of Dalit and Advantaged Janajatis showed higher rates of underweight and stunting, respectively. In agreement with the current study, Sapkota and Gurung reported that ethnicity was one of the determinants of child's stunting in disadvantaged ethnic group in Nepal (31).

The general finding was that households with a poorer standard of living also tend to have worse child nutritional status. This improvement of children's nutritional status with access to a sanitary latrine is in agreement with reports from other countries in South Asia (32), South America (33), and South and Central Africa (34) and could be primarily attributed to the household wealth and the decreased incidence of water-borne diseases, leading particularly to diarrhoea (35).

It was observed that the risk of a child being underweight and stunted was 1.28 and 1.33 times greater, respectively, in households who had no assets compared with households who had one or more assets. Similar results have been reported from other countries including India (36) and Bangladesh, which have shown that ownership of assets was associated with lower risk of severe or moderate stunting in children under five years old (37).

With regards to household construction materials, children living in households with poorer main floor material were more underweight than others living in not poor condition. Depending on their wealth, Nepalese families use local materials for construction of their houses (38).

According to the UNICEF conceptual framework of the causes of children's undernutrition, inadequate intake of nutrients (both quality and quantity) and disease are the two most important causes of undernutrition, which are further compromised by poor access to food, water, sanitation and health services. These causes are commonly referred to as food, care and health, which at the household level, are affected by basic factors such as income, maternal education, and other socio-economic and demographic factors (39). Therefore, evaluation of the relationship of socio-economic and demographic factors with children's nutritional abnormalities and anaemia is necessary in order to understand the underlying causes of these problems in Nepal.

It should be noted that in children, wasting is the result of acute undernutrition, while stunting is the result of chronic undernutrition and underweight is the result of both acute and chronic undernutrition. The first 1000 days of life is the time when there is a high risk for development of stunting, which continues in childhood (40). Therefore, it is to be expected that wasting would show a weaker association with socio-economic factors than underweight and that stunting would show stronger associations with these variables. This is the case in the current study.

It should be noted that there are hypotheses that link the household development over time to the risks of undernutrition (41). However, in this study, it should be taken into consideration that there are limits on the extent of causal inference that can be made from this report. High internal validity depends on the design of the research, implementation, analysis of trial and data collection with minimal bias. Since, this was a cross-sectional study using a standardised questionnaire which did not cover all aspects of nutrition, and exposure and outcome were measured at the same time, it was not possible to prove that the exposure variables were responsible for the outcome variables. Also, in spite of having a large sample size, when the result appeared significant, they only explained a small amount of the variance as the value of effect size was small.

\section{Conclusion}

The overall priority for nutritional health policy in Nepal should be reduction of undernutrition, as it profoundly affects children's health and development and as the high prevalence of stunting indicates that it is a long term problem. Geographical distribution of families should be considered for implementation of nutritional policies. In Nepal, special attention should be paid to the mountain zones especially in the Mid- and Far-western regions. Also, ethnicity, as one of the determinants of child nutritional status, should be considered. Maternal education should be targeted by authorities in Nepal in order to reduce children's undernutrition. As one of the causes of anaemia in Nepal is iron deficiency anaemia, the national iron supplementation program should be strongly continued with full coverage of high risk groups (children less than five years old).

\section{Conflict of Interests}

The authors declare that they have no competing interests.

\section{References}

1. Walker SP, Wachs TD, Gardner JM, Lozoff B, Wasserman GA, Pollitt E, et al. Child development: risk factors for adverse outcomes in developing countries. Lancet. 2007;369(9556):145-157.

2. United Nations Children's Fund. Tracking progress on child and maternal nutrition. New York: UNICEF; 2009.

3. World Health Organization. Child growth standards: length/heightfor-age, weight-for-age, weight-for-length, weight-for-height and body mass index-for-age: methods and development Geneva, Switzerland: WHO; 2006.

4. de Onis M, Blossner M, Borghi E. Prevalence and trends of stunting among pre-school children, 1990-2020. Public Health Nutr. 2012; 15(1):142-148.

5. Lutter CK, Daelmans BM, de Onis M, Kothari MT, Ruel MT, Arimond $\mathrm{M}$, et al. Undernutrition, poor feeding practices, and low coverage of key nutrition interventions. Pediatrics. 2011;128(6): e1418-1427.

6. McLean E, Cogswell M, Egli I, Wojdyla D, de Benoist B. Worldwide prevalence of anaemia, WHO Vitamin and Mineral Nutrition Information System, 1993-2005. Public Health Nutr. 2009;12(4):444454.

7. Martorell R, Leslie J, Moock PR. Characteristics and determinants of child nutritional status in Nepal. Am J Clin Nutr. 1984;39(1):74-86.

8. Hosono S, Okazaki M, Kagimoto S, Ogawa K, Matunaga K, Oishi T, 
et al. An evaluation of infants' growth in the Kingdom of Nepal. Acta Paediatr Jpn. 1998;40(4):350-355.

9. Ghosh A, Adhikari P, Chowdhury SD, Ghosh T. Prevalence of undernutrition in Nepalese children. Ann Hum Biol. 2009;36(1):3845 .

10. Ghosh A, Chowdhury SD, Ghosh T. Undernutrition in Nepalese children: a biochemical and haematological study. Acta Paediatr. 2012;101(6):671-676.

11. Siegel EH, Stoltzfus RJ, Khatry SK, Leclerq SC, Katz J, Tielsch JM. Epidemiology of anemia among 4- to 17-month-old children living in south central Nepal. Eur J Clin Nutr. 2006;60(2):228-235.

12. NDHS. Nepal Demographic and Health Survey 2006. Kathmandu, Nepal: Ministry of Health and Population, New ERA, and Macro International Inc.; 2007.

13. Central Bureau of Statistics. Nepal in figures. Kathmandu, Nepal: Government of Nepal; National Planning Commission Secretariat; CBS; 2010.

14. Central Bureau of Statistics. National Population and Housing Census 2011. Kathmandu, Nepal: National Planning Commission Secretariat, Government of Nepal; 2012.

15. Whelpton J. A History of Nepal. Cambridge: Cambridge University Press; 2005.

16. de Benoist B, McLean E, Egli I, Cogswell M. Worldwide prevalence of anaemia 1993-2005: WHO global database on anaemia. Geneva, Switzerland: WHO; 2008.

17. CDC. Current Trends CDC Criteria for Anemia in Children and Childbearing-Aged Women. MMWR Morb Mortal Wkly Rep. 1989;38:400-404.

18. CDC. Recommendations to prevent and control iron deficiency in the United States. 1998;47.

19. INACG. Adjusting hemoglobin values in program surveys. Washington, DC: ILSI Human Nutrition Institute; 2002.

20. World Health Organization. Haemoglobin concentrations for the diagnosis of anaemia and assessment of severity. Vitamin and Mineral Nutrition Information System. Geneva: World Health Organization; 2011.

21. Bennett L, Dahal DR, Govindasamy P. Caste, ethnic and regional identity in Nepal: Further analysis of the 2006 Nepal Demographic and Health Survey. Calverton, Maryland, USA: Macro International Inc.; 2008 .

22. Bennett L. Gender, caste and ethnic exclusion in Nepal: following the policy process from analysis to action. New Frontiers of Social Policy: Development in a Globalizing World. Arusha, Tanzania; 2005. pp. 1-48.

23. DFID. Regional dimensions of poverty and vulnerability in Nepal. UK: UK Department for International Development; 2013.

24. Codling K. Accelerating progress in reducing maternal and child undernutrition in Nepal. A review of global evidence of essential nutrition interventions for the Nepal Health Sector Plan II and MultiSectoral Plan for Nutrition. Final Consulting Report to the World Bank. http://nutritioncrsp.org/2011/12/march-symposium-nepal: The Global Nutrition, Nutrition Collaborative Research Support Program; 2011.

25. Marmot M. Achieving health equity: from root causes to fair outcomes. Lancet. 2007;370(9593):1153-1163.

26. Frost MB, Forste R, Haas DW. Maternal education and child nutritional status in Bolivia: finding the links. Soc Sci Med. 2005; 60(2):395-407.

27. World Health Organization. Nepal: National Health System profile http://www.searo.who.int/en/Section313/Section1523.htm. Accessed January 2012: WHO Regional Office for South-East Asia; 2007.

28. Nepal Food Security Monitoring System. A sub-regional hunger index for Nepal. Kathmandu, Nepal: UN World Food Programme in (WFP) Nepal; 2009.

29. Lovendal RC. Food insecurity and vulnerability in Nepal: Profiles of seven vulnerable groups. ESA Working Paper No. 04-10. Rome: Agricultural and Development Economics (ESA) Division, Economic and Social Department, Food and Agriculture Organization of the United Nations (FAO); 2004.

30. Sen P, Bharati S, Som S, Pal M, Bharati P. Growth and nutritional status of preschool children in India: a study of two recent time periods. Food Nutr Bull. 2011;32(2):84-93.

31. Sapkota VP, Gurung CK. Prevalence and predictors of underweight, stunting and wasting in under-five children. J Nepal Health Res Counc. 2009;7(15):120-126.
32. Kamiya Y. Socioeconomic determinants of nutritional status of children in Lao PDR: effects of household and community factors. J Health Popul Nutr. 2011;29(4):339-348.

33. Monteiro CA, Benicio MH, Conde WL, Konno S, Lovadino AL, Barros AJ, et al. Narrowing socioeconomic inequality in child stunting: the Brazilian experience, 1974-2007. Bull World Health Organ. 2010;88(4):305-311.

34. Willey BA, Cameron N, Norris SA, Pettifor JM, Griffiths PL. Socioeconomic predictors of stunting in preschool children--a populationbased study from Johannesburg and Soweto. S Afr Med J. 2009; 99(6):450-456.

35. World Health Organization. Equity, social determinants and public health programmes. Geneva: WHO; 2010.

36. Victora CG, Adair L, Fall C, Hallal PC, Martorell R, Richter L, et al. Maternal and child undernutrition: consequences for adult health and human capital. Lancet. 2008;371(9609):340-357.

37. Rahman A, Chowdhury S. Determinants of chronic malnutrition among preschool children in Bangladesh. J Biosoc Sci. 2007;39(2): 161-173.

38. NSR. Nutrition Survey Report: Jajarkot District, Nepal. 12/2008 ed. Kathmandu, Nepal: Sustainable Development Initiative Network Nepal; 2008.

39. UNICEF. Strategies of improving nutrition of children and women in developing countries. New York; 1998.

40. Leroy JL, Ruel M, Habicht JP, Frongillo EA. Linear growth deficit continues to accumulate beyond the first 1000 days in low- and middle-income countries: global evidence from 51 national surveys. J Nutr. 2014;144(9):1460-1466.

41. Levinson FJ, Balarajan Y, Marini A. Addressing malnutrition multisectorally: what we have learned from recent international experience? New York: UNICEF and MDG Achievement Fund; 2013. 